\title{
Rejigging Handiwork and Craft Education in Secondary Schools in Obudu L. G. A. of Cross River State Nigeria: An Intervention Strategy for Poverty Reduction, Economic Empowerment and Insecurity
}

\author{
Abel White Iheagwam, Julius Undiukeye Adie \& Willie Stephen Eteng \\ Department of Educational Foundations, Federal College of Education, Obudu, Cross River State, Nigeria
}

\begin{abstract}
The importance of the re-introduction of handiwork/craft Education in our secondary school system cannot be over emphasized. This study therefore Investigated how the rejigging of handiwork/craft Education in secondary schools can serve as an intervention strategy in reducing the level of poverty, ensure economic empowerment and guarantee adequate security of lives and property in Obudu Local Government Area, Cross River State, Nigeria. To achieve the purpose of this study, three research questions were posed, survey research design was adopted for the study. The population of the study was all the junior secondary school students in the Local Government Area numbering about three thousand eight hundred and sixty (3860) students. The sample size was five hundred (500) students randomly selected from the population. The questionnaire was used for data collection, and the data obtained was analysed using descriptive statistics of mean and standard deviation. The result obtained from data analysis revealed that rejigging handiwork/craft Education will help in promoting poverty alleviation, tackle insecurity and economic empowerment. Based on the result of findings, it was recommended among others that the teaching of handiwork/craft Education as a subject should be made compulsory in all secondary schools in Cross River State, as this will empower students economically.
\end{abstract}

Key Words: Handiwork, Craft, Education, Poverty Reduction, Economic empowerment and Insecurity

\section{INTRODUCTION}

$\mathrm{T}$ here is no gain saying that education plays a catalytic role in the all-round growth and development of every nation; as there exists a positive functional link between education (which deals with human capital development) and national development. However, presently in Nigeria and Cross River State in particular, the rate of graduates or youths unemployment has undoubtedly become a monster that has thrown much questions at the functionality of handiwork/craft and entrepreneurship education. Bolaji and Nneka (2012) supporting this assertion, argued that the rate of growth of students/graduates population is at a geometric progression while the growth of job opportunities can at best be described as being in arithmetic progression.

The benefits of the introduction of handiwork/craft education in the school system are enormous, for instance,
The United Nation World Tourism Organisation (2008) has put forward the potentials of handicrafts to include contributing significantly to sustainable socioeconomic development and poverty alleviation in local communities and creating substantial employment and income opportunities for young people and other disadvantaged segments of the society. According to a study by Pollanen (2013), craft offers a tool to handle the demands of the wasting and thruway, meaning that it promotes sustainable development by utilizing what others see as waste and helping them to appropriate the environmental consequence of their actions. In Eggleston's (2000) opinion, craft making makes unique demands on one's experience but gives us the opportunity to make some economic gains through the use of our hands. That the proceeds from the sale of products from handicraft can make our youths economically independent and reduce poverty in the society. Marchand's (2008) statement indicates that practical knowledge needs to earn the value and status it deserves that those who acquire this knowledge should be able to stabilize economically with the use of their hands. Similarly, Bennell (2007) indicates that the practice of handiwork among youths creates employment opportunities and promotes peaceful coexistence among them. This of course is true because in the course of collaborating to work, students establish friendship among themselves and promote their coexistence. According to Szydlowski (2008) handicraft has been proved to be a sustainable generator of income and employment in Vietnam, especially in rural areas. Ferreria and Lanjouw. (2001) on his part noted that in rural Brazil, 21.8 percent of the working population is engaged in rural handiwork practice as their primary means of employment. Sood

(2002)

noted that in India, handiwork created employment for millions of Indians regarded as craftspeople whose livelihoods and income are dependent on selling crafts, which makes it the second largest means of employment in the country. Contributing to the assertion that handiwork/ craft has poverty reducing potentials, Kapus (2012) noted that through handicraft cooperative membership, crafters are able to access livelihood assets, mostly economic, social, and human capital leading to poverty reduction. Ahamad and Yasmin (2012) also 
agrees that the handicraft sector has the potential to generate profitable employment opportunities to unemployed people and has an unlimited potential for economic development of a country and promote the security of the entire society. To Rogerson and Shithole (2001), the importance of catalysing the handicraft industries as a future employment creation tool should be emphasised in schools as this will help to keep many idle people off the streets and reduce crime in the society.

The quest for a solution to the increasing problem of unemployment which has resulted in the rise of poverty and insecurity is what most researchers say have necessitated the Federal Government of Nigeria in 1992 and 2004 respectively to take a policy decisions through the various institutions supervising agencies directing all the institutions of learning (primary, secondary and tertiary) in Nigeria to include handiwork/craft and entrepreneurship education in their curriculum; with technical support to carry out the programme (Okebukola, 2004; Raimi and Gabadeen, 2012). However, it has been noted that these laudable objectives for the introduction of handiwork/craft and entrepreneurship education into the Nigeria education system (curriculum), is yet to be fully achieved as many graduates still remain unemployed for a very long time.

Keen observations by researchers have shown that about $93 \%$ of craft and handicraft education which hitherto was a major component of the school curriculum, has totally eroded from the curriculum of secondary education, and replaced with/by direct cash payments and purchase of local craft items for presentation during local craft practical examination, thereby undermining the very essence of introducing the subject in the school system at that level, which basically was to give every student a practical and entrepreneurial skill upon graduation from this level of education, which it was believed will help to stem the tide of poverty, economic dependency, social vices and insecurity in the country and particularly, Obudu L. G. A. which is the area under study.

\section{STATEMENT OF THE PROBLEM}

The level of insecurity in Obudu Local Government Area of Cross River State has in recent times become so alarming. this is because personal observations and interview reports have shown that cases of robbery and theft or stealing has been reported and recorded on a daily basis, secret cult activities, prostitution and other social vices are on the increase, and communal clashes caused majorly by the struggles for farm lands by neighbouring communities are reported almost on a monthly basis.

A simple pilot investigation by the researchers to ascertain the remote causes for this scenario, reveals that poverty, poor economic situation of the people are responsible for the highlighted problems, and all of these most of the pilot study participants have attributed it to the inability of the education system, particularly, secondary education to teach the students these very important subject/courses in the curriculum, such as handiwork/craft making education and introductory technology which could make them economically self-reliant, and to live above the poverty line of one dollar per day. An idle hand they say is the devil's work tool, and their quest for livelihood and a means for survival is what has led to or resulted in the activities that pose security threat to the people and the entire local government. Government on its part has introduced different programmes to empower youths and take them off the streets but has yielded very low results. This study therefore is necessitated by the forgoing, and is aimed at addressing these challenges of insecurity in the land, through re-engineering handiwork/craft making education in the secondary schools in the area under study.

\section{PURPOSE OF THE RESEARCH}

The general objective of this study is to investigate how the rejigging of handiwork / craft education in secondary schools can serve as an intervention strategy in reducing the level of poverty, ensure economic empowerment and guarantee adequate security of lives and property in the study area. Specifically, the research focused on the following;

1. To ascertain how rejigging handiwork/craft making education in secondary schools can reduce poverty in the area

2. To determine how rejigging handiwork/craft making education in secondary schools can tackle the menace of insecurity in the area of study.

3. Examine how rejigging handiwork/craft making education in secondary schools can bring about economic empowerment and independence of the people in the area of study.

\section{RESEARCH QUESTIONS.}

The following research questions were formulated to guide the research;

1. How does rejigging handiwork/craft making Education in secondary schools help in the reduction of poverty in Obudu Local Government Area?

2. How can rejigging handiwork/craft making Education in secondary schools tackle the menace of insecurity in Obudu Local Government Area?.

3. How can rejigging handiwork/craft making Education in secondary schools bring about economic empowerment and independence among the people of Obudu Local Government Area?.

\section{RESEARCH GOALS:}

The goal of the research on "rejigging handiwork and craft education in secondary schools as an intervention strategy for poverty reduction, economic empowerment and insecurity" is to investigate how the almost extinct of eroded handiwork and craft education (training/learning) which was taken seriously in the secondary school system in the mid and late nineties, can help in reducing poverty level of people, make them become economically empowered and also help in abating 
the rate of insecurity in the area of study. The definitive goal of the research is to provide an educational framework for policy advocacy to support the present administration's change agenda in the areas of education, economic and national security. This will be done with the intent for ensuring a viable secondary school (education) system that will produce graduates who will have the practical skills for job creation and become economically empowered, thereby reducing drastically the level of poverty and security in the area of study and Nigeria at large.

\section{RESEARCH METHODOLOGY}

\section{A. Research design:}

The research employed survey research design. This design is considered appropriate because it took into consideration what had already existed in the area under study, as it relates the variables of the study. That is, handiwork/craft education, poverty level, economic situation and insecurity.

\section{B. Study population, sample and sampling technique:}

The population for this research project constitutes all the junior secondary school students in Obudu Local Government Area numbering about three thousand eight hundred and sixty (3860). While a total of five hundred (500) students served as the sample for the study, which was drawn through simple random sampling technique.

\section{Data type:}

This study used basically primary sourced data; which includes obtaining information directly from the respondents on the main research variables through the use of questionnaires,

\section{Data collection procedure:}

In collecting data for the study, the researchers paid visits to each of the sampled schools in the area targeted for the study and interacted first with the head of school and later with the teachers and non-teaching staff and finally with the students. It was explained to them the objective of the study and what they were expected to do in order to provide their own responses individually without external influence or fear of being reported. The researchers personally and with assistance from some field assistants, gave out the questionnaires to the respondents and collected them same day after completion. Five hundred (500) questionnaires were given out and were all collected, representing one hundred percent $(100 \%)$ return rate.

\section{E. Techniques of data analysis:}

The data collected was analysed using descriptive statistics of mean, and standard deviation, and presented in tables.

\section{RESULTS AND DISCUSSION}

\section{A. Results.}

The results of data analysis are presented in tables according to the research questions.

\section{Research question 1.}

How does rejigging handiwork/craft making Education in secondary schools help in the reduction of poverty in Obudu Local Government Area?

To provide answer to this research question, descriptive statistics of mean and standard deviation was used. Here, a benchmark mean of 2.5 was fixed for acceptance or rejection of a statement. The result is presented in table 1.

Table 1. Mean and Standard Deviation of Responses on Whether Rejigging Handiwork/Craft Making Education Can Help In The Reduction Of Poverty In Obudu Local Government Area.

\begin{tabular}{|c|c|c|c|c|c|c|c|}
\hline Statement & SA & A & $\mathrm{D}$ & SD & $\mathrm{X}$ & SD & Remarks \\
\hline $\begin{array}{c}\text { Teaching of } \\
\text { handiwork/craft in } \\
\text { secondary schools } \\
\text { can help to reduce } \\
\text { poverty in the } \\
\text { society. }\end{array}$ & 346 & 115 & 22 & 17 & 3.58 & 0.73 & Accept \\
\hline $\begin{array}{l}\text { Students can } \\
\text { support the efforts } \\
\text { of parents by } \\
\text { providing their } \\
\text { basic needs } \\
\text { through proceeds } \\
\text { from } \\
\text { handiwork/craft } \\
\text { products. }\end{array}$ & 258 & 100 & 77 & 65 & 3.10 & 1.09 & Accept \\
\hline $\begin{array}{c}\text { Teaching of } \\
\text { handiwork/craft in } \\
\text { secondary schools } \\
\text { do not add value to } \\
\text { the lives of } \\
\text { students }\end{array}$ & 61 & 148 & 108 & 183 & 2.17 & 1.06 & Reject \\
\hline $\begin{array}{l}\text { Students rather } \\
\text { become poorer } \\
\text { through } \\
\text { handiwork/craft } \\
\text { education since } \\
\text { they need to buy } \\
\text { materials for it. }\end{array}$ & 99 & 63 & 149 & 189 & 2.14 & 1.13 & Reject \\
\hline $\begin{array}{l}\text { Handiwork/craft } \\
\text { education reduces } \\
\text { the poverty level } \\
\text { of students since } \\
\text { they can make } \\
\text { money through the } \\
\text { skills acquired } \\
\text { from it. }\end{array}$ & 156 & 153 & 98 & 93 & 2.74 & 1.09 & Accept \\
\hline Grand Mean & & & & & 2.75 & & \\
\hline
\end{tabular}

Result of analysis as presented in table 1 indicate that the mean responses on items 1,2 and 5 which are $3.58,3.10$ and 2.74 respectively, are higher than the benchmark mean value 
of 2.5 and the statements are accepted. While the mean responses on items 3 and 4 which are 2.17 and 2.14 are below the benchmark and were rejected. However, the grand mean was 2.75 which is also above the benchmark. Since three out of the five statements were accepted and the grand mean is above the 2.5 benchmark, it is concluded that rejigging handiwork/craft making Education in secondary schools help in the reduction of poverty in Obudu Local Government Area.

\section{Research question 2.}

How can rejigging handiwork/craft making Education in secondary schools tackle the menace of insecurity in Obudu Local Government Area?

To provide answer to this research question, descriptive statistics of mean and standard deviation was used. Here, a benchmark mean of 2.5 was fixed for acceptance or rejection of a statement. The result is presented in table 2 .

Table 2. Mean And Standard Deviation Of Responses On Whether Rejigging Handiwork/Craft Making Education In Secondary Schools Can Tackle The Menace Of Insecurity In Obudu Local Government Area.

\begin{tabular}{|c|c|c|c|c|c|c|c|}
\hline Statement & SA & A & D & SD & X & SD & Remarks \\
\hline $\begin{array}{c}\text { When students are } \\
\text { involved in } \\
\text { handiwork/craft } \\
\text { making, it keeps them } \\
\text { busy and out of } \\
\text { crime. }\end{array}$ & 164 & 145 & 110 & 81 & 2.78 & 1.07 & Accept \\
\hline $\begin{array}{c}\text { Students who cannot } \\
\text { afford the cost of } \\
\text { handiwork/craft } \\
\text { materials may drop } \\
\text { out of school and } \\
\text { may become security } \\
\text { threats. }\end{array}$ & 202 & 78 & 127 & 93 & 2.77 & 1.16 & Accept \\
\hline $\begin{array}{c}\text { Students who acquire } \\
\text { handiwork/craft skills } \\
\text { are likely to revolt } \\
\text { against their teachers }\end{array}$ & 110 & 153 & 20 & 217 & 2.31 & 1.24 & Reject \\
\hline $\begin{array}{c}\text { Engaging students in } \\
\text { handiwork/craft } \\
\text { education will keekp } \\
\text { them off the streets. }\end{array}$ & 263 & 106 & 24 & 117 & 2.99 & 1.22 & Accept \\
\hline $\begin{array}{c}\text { Acquiring knowledge } \\
\text { in handiwork/craft } \\
\text { making can help to } \\
\text { engage some of the } \\
\text { street children as } \\
\text { apprentice. }\end{array}$ & 173 & 134 & 66 & 127 & 2.71 & 1.19 & Accept \\
\hline $\begin{array}{c}\text { Grand Mean } \\
\text { Rand }\end{array}$ & & & & & & & \\
\hline
\end{tabular}

Result of analysis as presented in table 2 indicate that the mean responses on items $1,2,4$ and 5 which are $2.78,2.77$, 2.99 and 2.71 respectively, are higher than the benchmark mean value of 2.5 and the statements are accepted. While the mean response on items 3 which is 2.31 is below the benchmark and was rejected. However, the grand mean of 2.71 was also above the benchmark. Since four out of the five statements were accepted and the grand mean was above the 2.5 benchmark, it is concluded that rejigging handiwork/craft making Education in secondary schools can help in tackling the menace of insecurity in Obudu Local Government Area.

\section{Research question 3.}

How can rejigging handiwork/craft making Education in secondary schools bring about economic empowerment and independence among the people of Obudu Local Government Area?

To provide answer to this research question, descriptive statistics of mean and standard deviation was used. Here, a benchmark mean of 2.5 was fixed for acceptance or rejection of a statement. The result is presented in table 3 .

Table 3. Mean And Standard Deviation Of Responses On Whether Rejigging Handiwork/Craft Making Education In Secondary Schools Brings About Economic Empowerment And Independence Among The People Of Obudu Local Government Area.

\begin{tabular}{|c|c|c|c|c|c|c|c|}
\hline Statement & SA & A & D & SD & X & SD & Remarks \\
\hline $\begin{array}{c}\text { Teaching } \\
\text { handiwork/craft } \\
\text { education in } \\
\text { secondary schools } \\
\text { will boost the } \\
\text { economy of the } \\
\text { community }\end{array}$ & 127 & 193 & 121 & 59 & 2.78 & 0.96 & Accept \\
\hline $\begin{array}{c}\text { Handiwork/craft } \\
\text { education is capital } \\
\text { intensive }\end{array}$ & 84 & 182 & 124 & 110 & 2.48 & 1.01 & Reject \\
\hline $\begin{array}{l}\text { Knowledge from } \\
\text { handiwork/craft } \\
\text { education can } \\
\text { empower students } \\
\text { economically }\end{array}$ & 211 & 193 & 26 & 70 & 3.09 & 1.01 & Accept \\
\hline $\begin{array}{c}\text { Handiwork/craft } \\
\text { education can make a } \\
\text { student self-reliant }\end{array}$ & 154 & 207 & 89 & 50 & 2.93 & 0.94 & Accept \\
\hline $\begin{array}{c}\text { Some } \\
\text { handiwork/craft } \\
\text { education teachers do } \\
\text { not teach students so } \\
\text { that they will not } \\
\text { compete with them } \\
\text { financially. }\end{array}$ & 177 & 171 & 56 & 96 & 2.86 & 1.10 & Accept \\
\hline Grand Mean & & & & & 2.83 & & \\
\hline
\end{tabular}

Result of analysis as presented in table 3 indicate that the mean responses on items $1,3,4$ and 5 which are 2.78, 3.09, 2.93 and 2.86 respectively, are higher than the benchmark mean value of 2.5 and the statements are accepted. While the mean response on items 2 which is 2.48 is below the benchmark and was rejected. However, the grand mean of 2.83 was also above the benchmark. Since four out of the five statements were accepted and the grand mean was above the 2.5 benchmark, it is concluded that rejigging handiwork/craft making Education in secondary schools brings about economic empowerment and independence among the people of Obudu Local Government Area.

\section{B. Discussion of findings.}

The result of findings in this study indicates that rejigging handiwork and craft education in secondary schools has helped in poverty reduction, the reduction of insecurity and economic empowerment in Obudu Local Government Area of Cross River State. 
In the area of poverty reduction, the result revealed that three out of the five responses

were accepted and the grand mean was above the 2.5 benchmark, it was therefore concluded that handiwork/craft making Education help in the reduction of poverty. This result is in agreement with The United Nations World Tourism Organisation (2008), who emphasised on the economic importance of introducing handicraft in the school system and stated that the huge potentials of handicraft include contributing significantly to sustainable socioeconomic development and poverty alleviation in local communities and creating substantial employment and income opportunities for the young population. Similarly, the findings of the study is also in line with Eggleston's (2000) opinion, that craft making makes unique demands on one's experience but gives us the opportunity to make some economic gains through the use of our hands. That the proceeds from the sale of products from handicraft can make our youths economically independent and reduce poverty in the society. The result is further in agreement with Kapus (2012) who noted that through handicraft cooperative membership, crafters are able to access livelihood assets, mostly economic, social, and human capital leading to poverty reduction.

In the area of tackling insecurity in the area, the result of findings revealed that four out of the five statements were accepted and the grand mean was above the 2.5 benchmark, it is concluded that handiwork/craft making Education can serve as a tool for tackling the menace of insecurity in Obudu Local Government Area. This result is in agreement with Rogerson and Shithole (2001), who stated that the importance of catalysing the handicraft industries as a future employment creation tool should be emphasised in schools as this will help to keep many idle people off the streets and reduce crime in the society. The result also agrees with Ahamad and Yasmin (2012) who argued that the handicraft sector has the potential to generate profitable employment opportunities to unemployed people and has an unlimited potential for economic development of a country and promote the security of the entire society.

Result of findings on the importance of handiwork/craft Education in economic empowerment and independence among the people of Obudu Local Government Area revealed that four out of the five statements were accepted and the grand mean was above the 2.5 benchmark, it was therefore concluded that handiwork/craft making Education brings about economic empowerment and independence among the people of Obudu Local Government Area. This result is in agreement with Marchand's (2008) whose statement indicates that practical knowledge of handiwork and craft needs to earn the value and status it deserves that those who acquire this knowledge should be able to stabilize economically with the use of their hands. Similarly, this result agrees with Szydlowski (2008) who stated that handicraft has been proved to be a sustainable generator of income and employment in Vietnam, especially in rural areas. The result also agrees with Ferreria (2001) who on his part noted that in rural Brazil, 21.8 percent of the working population is engaged in rural handiwork practice as their primary means of employment and economic empowerment. The findings further agrees with Sood (2002) who also noted that in India, handiwork created employment for millions of Indians regarded as craftspeople whose livelihoods and income are dependent on selling crafts, which makes it the second largest means of employment and economic empowerment in the country.

\section{Conclusion.}

Based on the findings of this study, it is concluded that the rejigging handiwork/craft education in our secondary school system is a boost to the wellbeing of the society in general and Obudu Local Government Area in particular. This is evident in the findings of the study which has proved that rejigging handiwork/craft education in secondary schools has helped in promoting poverty alleviation, tackling of insecurity and economic empowerment.

\section{RECOMMENDATIONS}

Considering the result of findings, the following recommendations were made.

1. The teaching of handiwork/craft Education as a subject should be made compulsory in all secondary schools in Cross River State, as this will empower students economically.

2. Government should organise periodic training programmes for teachers of handiwork/craft Education to keep them updated with new innovations in the subject matter and poverty reduction among students.

3. Head teachers and principals of schools should ensure proper supervision of teachers to ensure that students are made to participate in the practical aspect of the subject as this will engage them both in school and outside school there by keeping them off crime areas.

\section{REFERENCES}

[1] Ahamad, F. and Yasmin, E. (2012). Impact of turmoil on the handicraft sector of Jammu and Kashmir. An economic analysis. International NGO Journal. 7 (5), 78-83. Retrived online. DOI: 10.5897/INGOJ12.020.

[2] Bennell, P.(2007). Promoting livelihood opportunities for rural youths. Knowledge and skills for development. Accessed from

http://www.ifad.org/events/gc/30/roundtable/youth/benell.pdf.

[3] Eggleston, J. (2000).Learning through making: the crafts council Research. In J. Eggleston (Ed.), Teaching and learning Design and Technology. (134-146) Continuum: London.

[4] Ferreria, F.H. and Lanjouw, P.(2001). Rural nonfarm activities and poverty in the Brazilian northeast. World Development, 29(3), 509-528.

[5] Kappus, M. (2012). Understanding the impact of handicraft cooperative participation on livelihood strategy(asset accumulation and resiliency) among women: A quantitative case study from Kigali, Rwanda. Unpublished Master's thesis, Lund University. 
[6] Marchand, T.H.J. (2008).Muscles, morals, and mind: craft apprenticeship and the formation of person. British Journal of Educational Studies, 56(3), 245-271.

[7] Pollanen, S. (2013). Homing and downshifting through crafts. In U. Harkonen (Ed).Reorientation of teacher education towards sustainability through theory and practice. Proceedings of the $10^{\text {th }}$ International JTEFS/BBCC Conference. Sustainable development. Culture. Education. (275-290).Kopijyva Oy: Joensuu.

[8] Rogerson, C.M. and Shithole, P.M.(2001). Rural handicraft production in Mpumalanga, South Africa: organisation, problems and support needs. South African Geographical Journal. 83, 149158.

[9] Sood, A. (2002). Crafts as a sustainable livelihood option in rural India. Unpublished doctoral dissertation proposal. University of London, England. Accessed at http://www.livelihoods.org/lessons/Thematic/Craft diss.doc.

[10] Szydlowski, R.A. (2008).Expansion of the Vietnamese handicraft industry: From local to global. Unpublished Master's thesis, center for international studies of Ohio University. Retrived from file://C:/Users/OyekunleOA/Downloads/ohiou1218497546.pdf.

[11] United Nations World Tourism Organisation. (2008). Tourism and handicrafts. Madrid, Spain Retrived from https;//pub.unwto.org/WebRoot/Store/Shops/Infoshop/4947/9D4A 139DI/F45C/D0A6/C0A8/0164/8IC3/081216_turismo_religioso_c ordoba_exerpt.pdgf. 